\title{
Understanding New Consumption Sites of Internet Cafe in Yogyakarta, Indonesia
}

\author{
Tangguh Okta Wibowo ${ }^{1}$, Wening Udasmoro ${ }^{2}$, Ratna Noviani ${ }^{3}$ \\ ${ }^{1}$ Doctoral Student at Department of Media and Cultural Studies, \\ The Graduate School, Universitas Gadjah Mada \\ (email: tangguh.okta.w@mail.ugm.ac.id) \\ ${ }^{2}$ Corresponding author. Lecturer at Department of French Literature, \\ Faculty of Cultural Sciences, Universitas Gadjah Mada \\ (email: udasmoro@ugm.ac.id) \\ ${ }^{3}$ Lecturer at Department of Media and Cultural Studies \\ The Graduate School, Universitas Gadjah Mada \\ (email: ratna.noviani@ugm.ac.id)
}

\begin{abstract}
In the Indonesian context, we did not find any previous study on internet cafes that discussed the transformation from warnet to internet cafe. Based on our study in Yogyakarta, we found a new internet cafe style that we did not find in other cities. This study offers a new understanding of analyzing internet cafes that users not only consume a computer to access the internet, but they "consume" space as well. This study aims to explore that transformation and to reveal the expansion of consumption patterns. This study emphasizes the empirical investigation to gather the data. We conducted qualitative in-depth interviews and observations from January to June 2018. We also examined several previous studies about internet cafes to expose a gap that can be extended in this study. Based on findings, we found that the transformation from warnet was a way to survive amid mobile technology. This transformation gives an implication to the new means of consumption. However, the expansion of consumption patterns can be explored from the consumption of space and digital content. Overall, digital content is the new insight to understand that internet cafes are not only a place to copy contents, but this can be seen as a symbol of empowerment to local users. Therefore, internet cafes can be seen as media-industry bottom lines to promote a culture of resistance to digital content without going to the store or going to the cinema.
\end{abstract}

\section{Keywords:}

consumption; digital content; internet cafe; Yogyakarta; warnet

\section{Introduction}

Warnet (warung internet) is based on a small place equipped with several computers separated by booths with an internet connection and rented out per hour (Lim, 2003a). The presence of several warnets could be accessed by the public to access various information since 1996 in Indonesia (Hill \& Sen, 1997). Starting in the 2000s, internet cafes in the Indonesian region, the Special District of Yogyakarta, transformed from warnet. They have used an internet cafe billboard rather than a warnet billboard for a marketable name presently. They show some improvements to functions, facilities, and infrastructure. Until 2018, internet cafes business in Yogyakarta was dominated by two big chains in a town; those are internet cafe group A with seven branches and $B$ with four branches. The names of the group are fictionalized to guarantee anonymity

The transformation from a warnet to an internet cafe is not just the change of their 
name. Internet cafes accommodate the form of changes in the shape, function, facilities, and the way users are involved in consumption practices. Nowadays, mobile technology leads to a mundane picture that internet cafe business is decreasing (LeBlanc \& Shrum, 2017). It is the same with the growth of internet cafes in Yogyakarta that can be said contradictory to the development of technology. The ownership of technological devices has permeated in everyday consumers' life, such as WiFi in domestic and public space. Nevertheless, those technologies do not prevent them from visiting the internet cafe.

To illustrate the difference, based on our observation, we had visited many internet cafes in big cities in Indonesia, for instance, Denpasar, Jakarta, Bogor, Malang, Surabaya, and Semarang. We did not find the same format of internet cafe business like the condition in Yogyakarta. Those internet cafes are well known as a place for playing online games. All computers are equipped with standard graphics cards, high-speed connections, facilities, and all peripherals certified by Nvidia in the Asia Pacific region (Goenawan, 2018). On the contrary, internet cafes in Yogyakarta are not provided online games, but they provide another concept in leading new consumption practices for users. Even, we did not find the essential characteristic insight of connectivity in internet cafes like previous internet cafe's studies.

Based on observations, internet cafes in Yogyakarta have local servers that can be accessed by users. These servers contain thousands of digital contents, such as MP3s, music videos, images, gadget applications, films, software, and e-books, all of which can be copied by visitors for free. A new need for copying digital content and watching movies at internet cafes has never been encountered before in warnet or at internet cafes in another city. It indicates the existence of a new need, including how consumers consciously bring a hard disk as a mandatory property when it comes there, and gives a contribution to illustrate that there is an expansion of consumption patterns in the internet cafe.

Moreover, the internet cafe is designed aesthetically to attract visitors, not only to access the internet, but also to "consume the space" provided and the availability of cafes. Thus, a place is culturally constructed (Urry, 1995, p.2). Implicitly, the internet cafe room is not neutral. The form of internet cafe has standardization from the aspect of infrastructure, technology, spatial, and services in every branch. It means that all the branches do not have significant differences with another branch.

Based on the explanation above, this study examines the contradiction of why the people of Yogyakarta are still loyal to visit internet cafes nowadays. The empirical questions are addressed: (1) how does the transformation of a warnet into an internet cafe can be made to survive in the midst of the development of mobile technology? and (2) to what extent have internet cafes played a role in creating new consumption patterns? To answer these questions, we examine the previous studies about internet cafes from around the world to provide a depiction of the knowledge that they provide through the presence of computer technology in internet cafes and an overview of how internet cafes give implications for consumption patterns. Second, we review a brief history of warnet in Indonesia to depict the transformation from warnet to internet cafes. Next, we use a technosocial approach (Laegran \& Stewart, 2003; Lægran, 2009) to examine the spatial practice that users are not only using a computer as their activity, but they are "consuming" space as well. Last, we use Benjamin's (2001) view about the concept of aura to see its relation to the reproduction era of digital contents.

\section{Literature Reviews \\ Connectivity, space, and cafe's atmosphere}

In 1994, the first internet cafe emerged in London, namely Cyberia. It brought the concept 
of a public space that provided computer and internet access, and food and beverages (Liff \& Laegran, 2003; Mutula, 2003). With the appearance of an internet cafe, the users have a choice to access the internet in a cafe ambiance (Liff \& Laegran, 2003). In most cases, the term "café" depicts a public space that offers more private and protective space than the other public spaces. It indicates a fluid relationship between the private and the public area in the cafe. Spatial practice reflects the expression of existing social activities. The term "affective community space" was used to explain the cafe and food bar in the cafe as a social space for caring for each other (Warner et al., 2012). A cafe is valued as a successful business when it can attract visitors to come again. It was seen by considering several important factors that support the cafe, such as decoration, food and beverages, and the availability of online games. These facilities are recognized as sites for creating the atmosphere wanted by the users (Lægran \& Stewart, 2003).

The previous studies have primarily highlighted the consumption activities to use connectivity and space in an internet cafe. The connectivity describes that users can do some activities that go beyond location. In this case, a local and global connection to be conducted in seconds. Geographically, internet access allows users to minimize or even dismiss that distance. It can be symbolized as the death of distance in the borderless world (Ohmae, 1995; Pratt, 2002). The several studies discussed specifically a cultural space used for doing meaningful activities during the leisure time for entertainment, searching information, improving particular abilities and skills, and online social networking (Lee, 1999; Räisänen, 2006; Gürol \& Sevindik, 2007; Leon, 2007). Several other activities were also carried out, such as looking for job application (HydeClarke, 2006), gambling, online education or online courses, and e-commerce for online shopping (Mutula, 2003), and a place to operate illegal activities as well, such as planning an abduction and drug transaction (Qiu, 2013).

Furthermore, internet cafes also underline the presence of the cafe's atmosphere, which refers to the communities who use it as a place for meeting or individuals who want to spend their time without using a computer only by ordering some foods or drinks. The key to attracting visitors to come regularly is a place to "be consumed" (Warner et al., 2012). Meanwhile, internet cafes are configured by technology and users; hence the approach is not only focused on users, but the inter-relation of two agents: human and non-human (Warner et al., 2012).

According to Laegran (2009, p. 61), technosocial practices are built on the conception of users and technologies that are co-constructed together. In addition, space is a part of the process of co-construction between users and technology, while the internet is constructed through a place in the process of ongoing activities in the internet cafe. Technosocial approach gives benefit to see that the space in internet cafes is produced through the roles of technology. This technology permeates in the consumption pattern of the users. The use of technosocial space from Laegran and Stewart (2003; Lægran, 2009) helps to avoid a deterministic view between technology or social.

The theoretical framework above helps us to understand the technosocial practices in an internet cafe. Nevertheless, several internet cafes in the context of Yogyakarta are different if we compare to other cities in Indonesia. In the different context, internet cafes in Yogyakarta transformed from a warnet into an internet cafe form. Starting in the 2000s, they used the merging concept from internet kiosks (warnet) and the presence of cafes. Then, the delineation of the differences is focused on the new concept of internet cafes in Yogyakarta. While the idea of an internet cafe is not new, it constitutes the transformation of 
the widely known warnet. The transformation can be determined as a condensed process that leads to a substantial reorganization of patterns of socio-environmental interaction. The difference in the effects of these differences can be seen from the shape and structure of the transformation, so that this can shape the characteristics of a particular phenomenon (Müller \& Kirleis, 2019). This transformation can be viewed from the usage of internet cafe's space from the owner's and consumer's side, because it is in line with the history of the first presence of internet cafes in Indonesia.

\section{Methods}

This study emphasizes the empirical investigation to obtain the data. This method covers qualitative in-depth interviews (Pickering, 2008 , p. 4) to build a better understanding of the meaning production from meaning makers directly based on a micro-scale (Pickering, 2008, p.70). We had done several procedural steps. First, we conducted a participative observation in several internet cafes in Yogyakarta. This observation was done by visiting and being a user in the internet cafe. For understanding the issue, this study uses a case study approach. We observed all internet cafes of groups $A$ and B, precisely from January until June 2018 . The observation focused on the components as followed: technology used, users' activities, facilities, infrastructure, and the service system.

Second, we conducted face-to-face interviews with the managers of each group, because they, as a key person, have an essential role in designing and controlling the operation of all internet cafes. To gain their trust in interviews, we promise to use anonymity when mentioning the name of the internet cafe. That is why we use the initial name in order to preserve confidentiality. As Crow and Wiles (2008) said, they state that the use of pseudonyms for the study's location is to guarantee that this location cannot be disseminated again in reports or other presentations.
After the observations, we decided to limit the study on two internet cafes of each group. The reason for choosing the two is to achieve a better understanding of micro-scale cultural production for revealing the detailed new means of consumption in an internet cafe. To do this, we have confined the case study on two internet cafes from two groups of $A$ and $B$, namely internet cafe $X$ and $Y$. These internet cafes were chosen because they are in a head-to-head location of one street: Kaliurang Street in Yogyakarta. This street is one of the crowd-centers of student life in Yogyakarta because it is surrounded by some universities, such as Universitas Gadjah Mada, Universitas Negeri Yogyakarta, and Permata Indonesia Yogyakarta Health Polytechnic. Furthermore, the data from our interview results are transcribed and analyzed as well as the observation results to provide a whole picture of how internet cafes in Yogyakarta produce aesthetic space to create new consumption patterns in internet cafes. Also, we explore how does the internet cafe transform from warnet to survive in this digital era and what are the implications for consumers. Last, to analyze from the consumers' side, we also conduct in-depth interviews with ten informants. All informants are obtained using a random sampling method. They are the consumers from two different internet cafe groups with an average age between 20-30, and most informants are students from universities near the internet cafe.

\section{Result and Discussion}

\section{The expansion of consumption pattern in the local context}

In the local context of Indonesia, warnet was adapted from the appearance of traditional warung (a stall that sells food). Warung is a space for the society at micro-level in which it is possible to have a warm conversation. In addition, the concept of booths comes from warung using krepyak (bamboo window curtain) (Hill \& Sen, 1997; Lim, 2003b). From 1995 to the end of 1999, warnet grew into a high- 
tech cottage industry. It affected the ownership of a warnet, which was previously owned by an individual to an individual who owned some of them around a city (Hill \& Sen, 2005, p. 65). Warnet with its slogan of "making the internet widely available for everybody, especially students" and "everything is provided here," was successful in attracting college students and serving all of their needs (printing machine, CD, and scanner) (Lim, 2003b).

In Yogyakarta, warnet proliferated in 1996. It provided easy access for users who could not afford the internet subscription at home or did not have a computer (Hill \& Sen, 1997). According to the manager of internet cafe A, the embryo of internet cafe in Yogyakarta was started from warnet. A warnet had been operated since October 1996. In the next year, warnet A shifted into using the label of internet cafe by adding other facilities, such as the existence of cafe, widescreen monitor, two headphones, and the availability of multimedia content (movies for rental in a form of CD, copied in a server, and provided for users freely).
Furthermore, warnet A used an internet cafe as its label because the negative stigma was embedded in warnet. At the beginning of the presence of warnet in Indonesia, it was popularly known as a place to access pornographic content, a place for ditching for students to play an online game (Hindarto, 2008), and a place for prostitution by some groups of students (Tarigan, 2018). As the manager said:

"On the outside, many warnets have negative connotations, whatever they are used for any activities because the height of booths is high. And that is what we do not want. In (internet cafe) here, we have a booth, but the height is about $120 \mathrm{~cm}$, so when people stand, (we) can see the activity of the users inside the booth, so we can control (the activity)" (Manager internet cafe A, December 11, 2018).

Starting in the 2000s, internet cafe A has six branches (built-in 2000, 2007, two branches in 2009, 2010, and 2013). In 2012, they changed the small business into a corporation. On the

Figure 1. The Warnet's Atmosphere

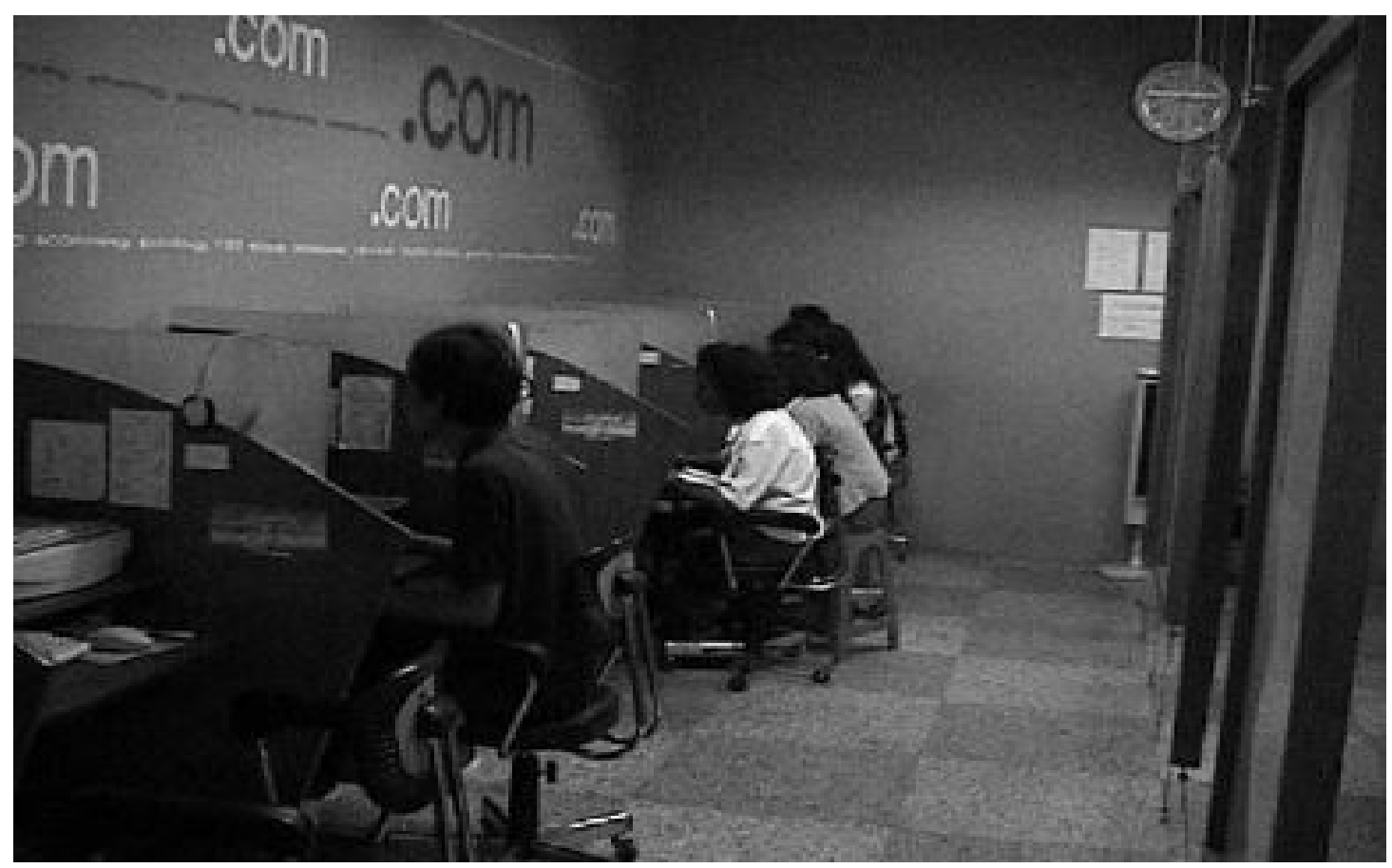

(Source: Lim, 2003a) 


\section{Figure 2. The Internet Cafe's Atmosphere}
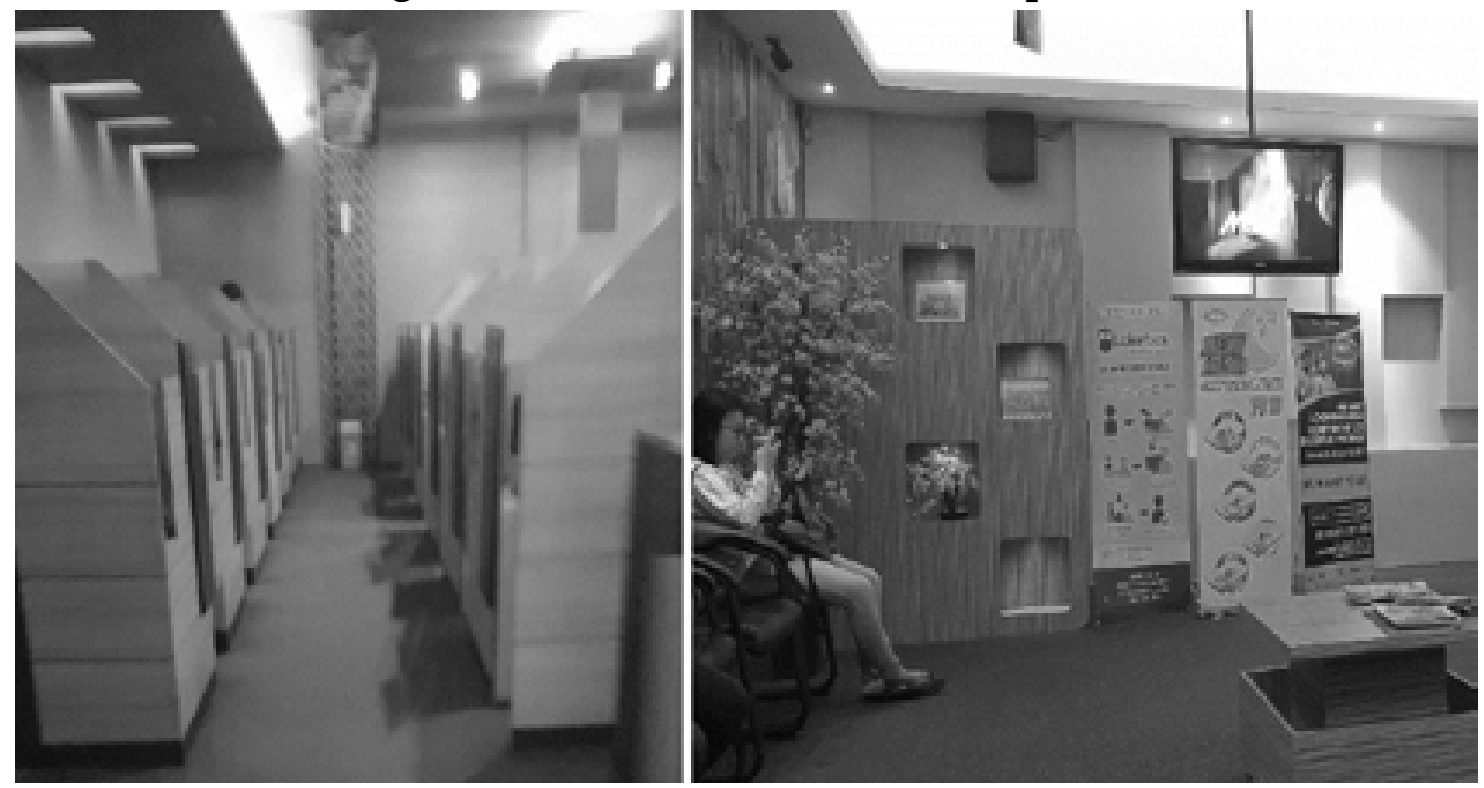

(Source: Author, 2018)

Table 1.

The Comparisons Between Warnet and Internet cafe

\begin{tabular}{|c|c|c|}
\hline Comparison & Warnet Design & Internet cafe design \\
\hline Room & Simple space design & Modern space design \\
\hline Booths & $\begin{array}{l}\text { Limited space on each booth without door, } \\
\text { electric fan on top }\end{array}$ & $\begin{array}{l}\text { Designed for two users with a door in each } \\
\text { booth, Air-Conditioner coverage }\end{array}$ \\
\hline Smoking room & Only single room or not allowed & $\begin{array}{c}\text { Separated room with good circulation for } \\
\text { smoking in AC room }\end{array}$ \\
\hline Waiting room & Not available & VIP waiting room with 32-inch TV \\
\hline Computer desk & $\begin{array}{c}\text { A small monitor (around 15-19 inches), } \\
\text { one headphone, regular chair }\end{array}$ & $\begin{array}{c}\text { An LED monitor (24-inch), two headphones, } \\
\text { webcam, comfortable sofa }\end{array}$ \\
\hline Facilities & $\begin{array}{l}\text { Printing and scanning machine } \\
\text { in operator room }\end{array}$ & $\begin{array}{c}\text { Printing and scanning machine in operator } \\
\text { room }\end{array}$ \\
\hline Toilet & Squat toilet/closeted toilet (it depends) & Closeted toilet \\
\hline Praying room & Not available & Small musholla \\
\hline Cafe & $\begin{array}{l}\text { Not available, only beverage fridge or some } \\
\text { snacks in operator room }\end{array}$ & $\begin{array}{l}\text { Users can order food and beverages from } \\
\text { computer screen }\end{array}$ \\
\hline Free Space & Not available & $\begin{array}{l}\text { Free space/learning space with selling WiFi } \\
\text { (hotspot) }\end{array}$ \\
\hline An hour access fee & 2000-3000 IDR & 6000-7500 IDR \\
\hline
\end{tabular}

(Source: Author, 2018)

other side, in Yogyakarta, there is another corporation of internet cafe. Internet cafe B has four branches (built-in 2006, 2009, 2010, and 2016). As producers, they try to compete in creating new needs regarding the needs of multimedia content as one of the facilities that they offer, starting from the antivirus, e-book, and movies. The differences between warnet and internet cafe can be seen in figures 1 and 2 .
Table 1 is a detailed explanation for comparing the situation of warnet and internet cafe from Figures 1 and 2 . As we can see, warnet prioritizes the prominent service, internet access that is highlighted, and the existence of supporting facilities such as printing and scanning machines. In contrast, an internet cafe emphasizes the design, environment and comfort of the space itself. The provided 
facilities affect the price. Internet cafe charges around 6000 to 7500 IDR per-hour to access the computer with an internet connection, while warnet charges typically around 2000 to 3000 IDR per-hour. It depends on the location; for example, the internet cafe that is located near a campus, a school, or boarding houses is possible to charge a higher cost per hour.

However, the choice to determine a theme is to increase sales, add value to the product, and sell at high prices. This themed strategy is purposed to attract visitors by creating an atmosphere that can enable consumers to have a unique experience than similar products in other places. In other words, what is being sold now is not services that are sold, but experience itself (Åstrøm, 2019, pp. 14-15). Therefore, the production of space and facilities can be positioned as the way of the business owner to make consumers always actively consume products through unique experiences. In an internet cafe, users can use facilities provided to watch movies, such as a modern room and air conditioner (AC), closeted booths, a computer with a pair of headphones, and a comfortable sofa. Those indicate that users also "consume the space" in an internet cafe.

\section{The dimension of new means of consumption in the internet cafe}

Internet cafe $X$ and $Y$ have a similar format. Both have free space and booth space. These two spaces are in a separate place. In the following sections, we will expose the qualitative description of these two spaces.

\section{Free space}

Free space, like a cafe in general, is modernly designed by emphasizing the architectural design and lights aspect. This space provides some tables and soft chairs for customers who come bringing their laptops, meeting with the community, or just enjoying the cafe by ordering food and drinks. Consumers can buy WiFi vouchers, which are sold to access the internet using their own devices. Consumers are also able to order some foods and drinks like they are in a cafe. The menu offered is similar to the menu in a typical cafe but at an affordable price. Moreover, the experience of consuming an internet cafe is different from a cafe, where the technology is in the middle of an interaction with the community. That situation implicates the frequent access to their laptop and smartphone with WiFi connection, and sometimes it is interspersed by conversations with friends. Internet cafes provide a free space that is consumed as a hangout place in the intersection with technology.

\section{The booth spaces}

Each internet cafe has a booth space to access the computer in a private booth. Both internet cafes divide the room into two areas: smoking and non-smoking areas; each area equipped with AC. They have similar physical specifications with modern design. However, internet cafe $\mathrm{Y}$ has a door in each booth. It gives the users a private space to provide them privacy for their activities in front of the computer.

All booths have a computer equipped with components such as a 24-inch LED monitor, headphones, sofa, and AC. The manager of Internet Cafe $Y$ stated:

"What is visible from an internet cafe physically is the appearance of the room, if the ordinary warnet has a computer desk, booth, and chair...However, the internet cafe has the concept of room and lighting arrangement that is more likely a cafe lounge," (Manager internet cafe B, December 28, 2018).

In other words, the atmosphere symbolizes an aesthetic space. It will attract the users to 'consume the space' that can be captured by the smartphone's camera. This experience can be viewed from users who upload their activity when in the booth or free space on social media 
(especially Instagram) by tagging the location where they are at, at that time. In other words, the space in the booth of the internet cafe is produced as an instagrammable space. Users can consume this space locally or trans-locally through the photo they upload.

In a consumption culture, what is consumed by consumers shows prestige and used to classify one's status. At the same time, consumers use images, signs, and symbols of goods to present their desires to fulfill emotional pleasures (Featherstone, 2007, p. 27). They gain joy from the visual consumption for every photo that they share. It is to show that they become part of a community that is familiar with technology (Lee, 1999). In other words, ICT has immersed in the users' lives, affected relationships, privacy, budget, and values (Portus, 2015). Urry (1995) argues that other people can consume someone's identity in a place; hence other people can also "consume" that place. Moreover, smartphones as the medium embedded in daily life gives the freedom for users to be more active in ritualizing their social relations (Hjorth, 2007). This moment reflects users' experience that becomes a site for the public gaze to be seen as a technology-savvy community.

Implicitly, three crucial components play a role at that moment. First, internet cafes provided the booth as an aesthetic space for publication and consumed trans-locally through social media. Second, internet cafes provided technology in the booth as an up-todate technology; hence, this technology can be viewed as an integral part of material objects consumed visually, aside from the aesthetic space design. Third, the role of the smartphone as mobile technology becomes an embedded part that is always brought by users in their daily life. Smartphones play a role in place consumption.

Those three highlights at least can answer the earlier question in regard to why people still visit an internet cafe nowadays. First, the image of the computer has changed from something associated with social activity into a tool for communication purpose, entertainment during the spare time, and playground in a public space (Laegran \& Stewart, 2003). The production of aesthetic space in internet cafes changes the image of the computer from a place that is only used to access the internet or purposes as been said by Laegran and Stewart (2003), into an aesthetic space that is bound to the up-to-date technology. This condition implies the more extensive lifestyle as a symbolic center of consumption: the modern hangout place.

\section{Internet cafe creates a gigabyte need}

Besides the aesthetic space, internet cafe $X$ dan $Y$ expand the facilities that can be accessed by users, which is the digital content. This fact gives a gap with previous studies about internet cafes in the global stream. This gap lies in the digital content that can be accessed even without any internet connection. In both internet cafes, they provide lots of digital contents, such as mp3 songs or video clips, movies, television shows, and series, software, games, e-books, and comics. A thesis from Anshari ( 2014b), he explores that the consumers' behaviors are not only accessing the internet, but they copy movies provided by the internet cafe.

Moreover, this practice gives a contrast to previous studies about internet cafes in the global stream that internet connectivity in the internet cafe is essential. However, through this finding, something new can be explored. The time spent will shift to the activity of copying digital content from the internet cafe's server to the user's external hard disk as well as the activity of the user in choosing which content to be copied.

The digital content is a part of the local computer that can be accessed without internet connectivity. This study expands the previous study concerning access to watching movies 
from Wibowo's (2019) study. The movie files in movie streaming websites are only saved in cloud storage, and users have to use the internet connection for streaming or downloading movie files they want to watch. From this study, users in the internet cafe are able to collect movie files for themselves or distribute them to other people (Anshari, 2017). Then, it leads to a new insight that digital contents in the internet cafe can be positioned as disposable content. The users do need to think twice to delete a movie file when their hard disk is in full capacity because they can copy again for free in some seconds or copy from friends. The internet cafe creates a new need as well, that is a gigabyte need. This need makes the role of the external hard disk becomes an important electronic device to be brought by the users as the storage media to save digital content. It leads to a new dimension of consumption site.

Furthermore, the time has implications for the shifting of user's intensification, from the utilization of internet access to the process of choosing content and waiting for the copying process to be done. As they wait, they do other activities, such as talking face to face with friends, using a smartphone, or if the user comes alone, he or she is busy watching movies or choosing other content. That practices implicate a perspective that the internet connection becomes a part that is not too important.

Those activities can be seen from the clarification of all informants. They recognize that they are going to an internet cafe to access the collections of digital content provided by the internet cafe. All internet cafes have a big capacity of servers to store all digital files. As one of the represented informants, she said:

"For me, I need their media collections (then internet access), such as movies, Korean series, and western. Even the music, they have a complete collection of music. In the past, it might have only been in the form of cassettes, old artists, but they already had iTunes format, mp3s, so I only copied all of them" (Informant A, November 22, 2018).
As represented by informant $A$, the users only use internet connection for complementary needs, such as searching for the list of recommended movies. It is because the function of a computer for certain activities such as accessing email, playing online games, and chatting has been replaced by the laptop, tablet, or smartphone. The users are usually using their smartphone for chatting while waiting for the copying process to be done. Then, the hard disk also plays a role in this consumption practice. Hard disk's capacity and speed affect how many content users can keep, how long it takes to copy, and the implications after digital content are reproduced, such as watching it on a laptop at home or connecting it with television that supports the digital format.

The existence of technology plays a role in the technosocial practices in the internet cafe. Hence, technology in an internet cafe affects the production of space in an internet cafe. Locally, this production becomes more complex, because the intersection is not only located on the internet, technology, and technosocial space, but also the digital contents.

\section{The refusal of the original distribution of digital content}

In the context of an internet cafe in Yogyakarta, it is a place that accommodates a variety of digital content from online forums or resources on the internet. It provides digital content on its local server. The internet cafe also offers a multimedia request feature to update its database based on the users' needs. The internet cafe provides digital contents free to charge. However, something that is free is not entirely free. According to logic, there is a cross-subsidy transaction, which is the service that must be paid for the subsidy provided. In other words, the users have to pay the price of computer access according to the running billing.

Furthermore, there is an implicit commodification of digital content. This 
commodification is not directly sold for every content that is copied, but rather the length of time to copy digital content that is a giga-sized file. The higher or better the quality of movie or software provided and the more digital content, the longer the time it takes for the users to copy the content. This leads to the opinion of the users who came to an internet cafe as their central alternative place to access films rather than coming to the cinema, renting DVDs on a rental basis, or downloading movies on the internet. Ease of access for digital content becomes the attraction of consumers always to visit the internet cafe to update the content. They have a rational reason to become a regular user. An informant said that:

"I just came here to copy digital content. Because at (my) boarding house, there is also wifi to make easy access for browsing information. For me, we need a very long time to download a game file. This case makes me go to the internet cafe. If you download it for yourself, it is better to go to the internet cafe and just copy. It is cheaper, not up to 10 thousand we can get 4-5 games" (Informant B, February 8, 2018).

A good quality game installer can approximately have a capacity of more than 10 gigabytes. Based on time and convenience for pursuing an interest in game installers, he visits an internet cafe to save so much time. Accordingly, as well as most informants, they feel an internet cafe is like a heaven for moviegoers. As one of the informants said:

"For example, I also agree with my friends, who are waiting for digital content. Because there is a movie that I'm too lazy to go to the cinema or I don't have any money, so I wait for the availability in an internet cafe. I have a story. My sister watched a movie in the cinema; she felt disappointed. She had spent money but felt disappointed. So, it's better to just wait for availability" (Informant C, October 13, 2018).
Some visitors consider that the main business of internet cafes is as a center for copying videos or other digital content (Anshari, 2014a). Thus, the internet cafe reflects the social and cultural transformation of accessing digital content. Internet cafes reformulate how the culture of copying digital content is mundane. Dematerialization from physical to digital products also contributes to this culture. It contributes to the cultural continuity of copying digital content into "natural" activities, without looking further into copyrighted files. The debate about piracy in the digital age cannot be quickly resolved, because the internet is still temporary. It means that the internet will continue to grow, and the law will procrastinate if it still considers media file sharing activities on the internet as piracy (Lessig, 2004).

Thence, internet cafes are not only viewed as socializing places where the people could socialize both online and offline (Binark et al., 2009)and thus this using practice empowers already existed social networks among the young people. The Internet cafés are the places where game culture is promoted among the young people as well. Places can be considered to be in a part of media-industry bottom lines (Strangelove, 2015, p. 34). Thus, it can be said if the presence of internet cafes can also be positioned as part of the bottom-line media for the refusal of official digital content distribution from the media industry. It should be noted that although all those digital contents infringe on copyright. It is not the realm or capacity of this study that addresses this issue. Nevertheless, it can be worth doing in further study.

The availability of digital content on internet cafe servers could be a space for mass-consumed digital content. It leads to the democratization of media distribution (Tyron, 2013; Wibowo, 2019). This kind of condition implies a hierarchy of the tastes consumed and also marks the homogenization of cultural products, as well as choices that enrich the appetite (Piliang, 2010, p. 432- 
434), so consumers have more power to personalize content (Strangelove, 2015, p. 144). Conceptually, the presence of a computer expands the possibilities of distribution, convenience, and multimedia functions. Second, the users have the freedom to access computers to personalize digital content that they want to copy.

Ozdemirci (2014, p. 158) reflects the digital files from the concept of Walter Benjamin (2001), "The Era of Mechanical Reproduction." There is a parallel relationship between the loss of the "aura/special atmosphere" of a work of art and the "massification" of digital files that signifies the result of mechanical reproduction. From this view, users are empowered and facilitated by the internet cafe to have an alternative option for copying digital content without purchasing in-store or going to the cinema, even using movie streaming websites like the study of Wibowo (2019).

Furthermore, we argue that users can also be said to be a form of their resistance in accessing digital content. The entertainment files that they copy from the local server to the hard disk indicate the process of moving or distributing content, that is, from the bottomline media to personal distribution. There is a high possibility that the copied content will also be redistributed again by the users offline and online. If we put aside the copyright rules for a moment, we could see another context.

\section{Conclusion}

We begin with an argument about the widespread usage of mobile technology, but the users in Yogyakarta still had been visiting an internet cafe. In some previous studies, they put forward connectivity, space and cafe atmosphere. Then, we expand the analysis of internet cafes through the existence of digital content. One reason there is a transformation into an internet cafe is to survive amid the onslaught of increasingly affordable internet access and modern and inexpensive technological devices. Therefore, we suggest that a transformation of the internet cafe creates a change in consumption patterns and brings a different consumption dimension that emphasizes space as a design space and digital content as a center of consumption. Moreover, the existence of digital content has implications for the high price spent to pay when going to the internet cafe. On another side, it gives a new insight into understanding a new theme of the study about internet cafes in Indonesia. However, the digital era provides more freedom in reproducing digital content. The digital contents give a new nuance of consumption patterns in an internet cafe. The users have an alternative opportunity for accessing copyrighted digital contents and internet cafes have played a role in creating this atmosphere in the local context. Thus, we argue that the new consumption practices in the internet cafes could be symbolized as the refusal of the original distribution of digital content. The internet cafe has a role as the bottom-line media to provide free copying digital contents.

\section{Acknowledgment}

This study is supported by Indonesia Endowment Fund for Education (LPDP) and a part of doctoral theses with the title "The consumption practices of internet cafe users in Yogyakarta." We would also like to thank two reviewers for their comments on this work.

\section{References}

Anshari, I. N. (2014a). All you can copy: rekomodifikasi dalam budaya mengopi video di warnet. Membayangkan Indonesia Baru, 548-559. Retrieved from https:// www.academia.edu/12772771/All_You_ Can_Copy_Rekomodifikasi_Dalam_ Budaya_Mengopi_Video_Di_Warnet

Anshari, I. N. (2014b). Pemahaman baru pembajakan digital dalam budaya mengopi: praktik dan implikasi budaya mengopi video di warnet 
di Yogyakarta. Thesis. Universitas Gadjah Mada.

Anshari, I. N. (2017). "Ngopi film di warnet": sirkulasi film dalam lingkup media baru (copying movies in internet kiosk: the circulation of movies in the scope of new media). Konferensi Film Indonesia. Retrieved from Unpublished material.

Åstrøm, J. K. (2019). Why theming ? identifying the purposes of theming in tourism. Journal of Quality Assurance in Hospitality \& Tourism, 0(0), 1-22. doi: 10.1080/1528008X.2019.1658147

Benjamin, W. (2001). The work of art in the age of mechanical reproduction. In G. D. Meenakshi \& K. Douglas (Eds.), Media and cultural studies (pp. 18-40). London: Blackwell.

Binark, M., Sütcü, G. B., \& Buçakçı, F. (2009). How Turkish young people utilize internet cafes: the results of ethnographic research in Ankara. Observatorio (OBS*) Journal, 3(1), 286-310. doi: 10.15847/obsOBS312009249

Crow, G., \& Wiles, R. (2008). Managing anonymity and confidentiality in social research: the case of visual data in Community research. Retrieved from http://eprints.ncrm.ac.uk/459/

Featherstone, M. (2007). Consumer culture and postmodernism (2nd ed.). London: Sage Publications.

Goenawan, M. A. (2018). ESports bikin warnet naik kelas. Retrieved August 8, 2018, from Detik.net website: https://inet.detik.com/ games-news/d-3834822/esports-bikinwarnet-naik-kelas.

Gürol, M., \& Sevindik, T. (2006). Profile of internet cafe users in Turkey. Telematics and Informatics, 24(1), 59-68. doi: 10.1016/j. tele.2005.12.004

Hill, D. T., \& Sen, K. (1997). Wiring the warung to global gateways: the internet in indonesia. Indonesia, 63, 67-69. doi: 10.2307/3351511

Hill, D. T., \& Sen, K. (2005). The Internet in Indonesia's New Democracy. New York: Routledge.
Hindarto, S. Y. (2008). Warnet masih jadi sarang mesum pelajar (internet kiosk is still a student's nasty nest). Retrieved February 23, 2019, from Oketechno website: https://techno.okezone.com/ $\mathrm{read} / 2008 / 12 / 01 / 55 / 169378 /$ warnet-masihjadi-sarang-mesum-pelajar)

Hjorth, L. (2007). Snapshots of almost contact: the rise of camera phone practices and a case study in seoul, korea. Continuum, 21(2), 227-238. doi: 10.1080/10304310701278140

Hyde-Clarke, N. (2006). The urban digital divide: a comparative analysis of internet cafés in Johannesburg, south africa. Review of African Political Economy, 33(107), 150-156. Retrieved from https://www. jstor.org/stable/4007119

Laegran, A. S. (2009). Technosocial space: connecting people and places. In P. Turner, S. Turner, \& E. Davenport (Eds.), Exploration of Space, Technology, and Spatiality: Interdisciplinary Perspectives (pp. 54-69). doi: 10.4018/978-1-60566-984-7.ch072

Laegran, A. S., \& Stewart, J. (2003). Nerdy, trendy or healthy? configuring the internet café. New Media and Society, 5(3), 357-377. doi: 10.1177/14614448030053004

LeBlanc, M., \& Shrum, W. (2017). The evolution of ghanaian internet cafés, 2003-2014. Information Technology for Development, 23(1), 86-106. doi: 10.1080/02681102.2016.1263594

Lee, S. (1999). Private uses in public: a study of an internet cafe. New Media \& Society, 1(3):331350. doi: $10.1177 / 14614449922225618$

Leon, K. J. L. (2007). Philippine sociological society a study of internet cafés: identity, freedom and communicative extension. Philippine Sociological Review, 55, 37-49. Retrieved from https://www.jstor.org/ stable/23898244

Lessig, L. (2004). Free Culture: How Big Media Uses Technology and the Law to Lock Down Culture and Control Creativity. United States: Penguin Press. 
Liff, S., \& Laegran, A. S. (2003). Cybercafes: debating the meaning and significance of internet access in a cafe environment. New Media \& Society, 5(3), 307-312. doi: $10.1177 / 14614448030053001$

Lim, M. (2003a). From war-net to net-war: the internet and resistance identities in indonesia? International Information and Library Review, 35(2-4), 233-248. doi: 10.1080/10572317.2003.10762603

Lim, M. (2003b). The internet, social networks, and reform in indonesia. In N. C. and J. Curran (Ed.), Contesting Media Power: Alternative Media in a Networked World (pp. 273-288). Lanham, MD: Rowman \& Littlefield Publishers, Inc.

Müller, J., \& Kirleis, W. (2019). The concept of socio-environmental transformations in prehistoric and archaic societies in the holocene: an introduction to the special issue. The Holocene, 29(10), 1517-1530. doi: 10.1177/0959683619857236

Mutula, S. M. (2003). Cyber cafe industry in africa. Journal of Information Science, 29(6), 489-497. doi: 10.1177/0165551503296006

Ohmae, K. (1995). The end of the nation state: The rise of regional economies. New York: Free Press.

Ozdemirci, E. G. (2014). Bit torrent: stealing or sharing culture? a discussion of the pirate bay case and the documentaries "steal this film” I \& II. In F. Martin \& A. James (Eds.), Piracy: Leakages from Modernity. California: Litwin Books.

Pickering, M. (Ed.). (2008). Research methods for cultural studies. Edinburgh: Edinburgh University Press Ltd.

Piliang, Y. A. (2010). Dunia yang dilipat: Tamasya melampaui batas-batas kebudayaan. Bandung: Matahari.

Portus, L. M. (2015). Internet literacy : levels of literacy among selected filipinos across economic classes. Plaridel Journal, 12(1), 158-179.
Pratt, A. C. (2002). Hot jobs in cool places: the material cultures of new media. In Cybercultures: Critical Concepts in Media and Cultural Studies. New York: Routledge.

Qiu, J. L. (2013). Cybercafés in china: community access beyond gaming and tight government control. Library Trends, 62(1), 121-139. doi: 10.1353/lib.2013.0021

Räisänen, P. (2006). The urban technospace: a study on internet cafés in Shanghai. Thesis. Lund University. Retrieved from https:// lup.lub.lu.se/student-papers/search/ publication/1327545

Strangelove, M. (2015). POST-TV Piracy, Cord-Cutting, and the Future of Television. Toronto: University of Toronto Press.

Tarigan, S. (2018). Warnet jadi tempat mesum siswa, terungkap saat petugas melakukan razia (internet kiosk becomes student's nasty place, revealed when officers conduct raids). Retrieved February 23, 2019, from Tribun Medan website: http://medan. tribunnews.com/2018/09/08/warnet-jaditempat-mesum-siswa-terungkap-saatpetugas-melakukan-razia)

Tyron, C. (2013). On-demand culture: digital delivery and the future of movies. New Brunswick: Rutgers University Press.

Urry, J. (1995). Consuming places. London: Routledge.

Warner, J., Talbot, D., \& Bennison, G. (2012). The cafe as affective community space: reconceptualizing care and emotional labour in everyday life. Critical Social Policy, 33(2), 305-324. doi: 10.1177/0261018312449811

Wibowo, T. O. (2019). Understanding movie streaming websites in indonesia as unlimited movie access in the digital era. Jurnal Komunikasi: Malaysian Journal of Communication, 35(2), 247-259. doi: 10.17576/JKMJC-2019-3502-15 